interferem na evolução do calo ósseo. Seis animais da espécie canina, de raças, idades e sexo variados, portadores de fraturas antigas foram selecionados do atendimento do HOVET UniFMU. As fraturas foram reduzidas cirurgicamente com fixadores trans-cutâneos e após primeiro controle radiográfico, às três semanas de evolução, em não havendo indícios satisfatórios de formação de calo ósseo os animais foram submetidos a tratamento com decanoato de nandrolona, na dose de $2 \mathrm{mg} / \mathrm{kg}$ pela via intramuscular num total de duas ou três aplicaçòes intervaladas por 15 dias. Foram realizados exames radiográficos controle a cada 15 dias após as aplicações. Os exames evidenciaram intensa proliferação do calo ósseo, os implantes ósseos puderam ser removidos em média aos 15 dias após a segunda administração de decanoato de nandrolona. Não foram observados clinicamente quaisquer efeitos colaterais relacionados ao uso do decanoato de nandrolona nas doses e frequência relacionadas anteriormente. Há necessidade de maiores avaliações sobre a utilização e efeitos sistêmicos do decanoato de nandrolona na posologia sugerida, porém, pode-se concluir que seus efeitos estimuladores na consolidação óssea são muito benéficos nas fraturas de consolidaçào lenta ou que tendem à não uniào.

\title{
99 - Utilização de agulha hipodérmica 25x07 trans- articular para correção da luxação congênita do cotovelo em cães da raça Pinscher. Relato de 6 casos
}

Maria, P.P.' ; Comunian, C.C. ${ }^{2}$; Valim, A.L.O'
1 - Docente da Pontifícia Universidade Católica, Campus Poços de Caldas, Poços de Caldas-MG e do Centro Regional de Ensino Veterinário de Espírito Santo do Pinhal, Espírito Santo do Pinhal-SP; Aluna do curso de pós graduação (nível doutorado) em cirurgia veterinária da Faculdade de Medicina Veterinária da Universidade Estadual Paulista (UNESP), Campus de Jaboticabal, Jaboticabal-SP

2 - Clínica e Diagnóstico Veterinário CENTRE, São João da Boa Vista-SP

A luxação congênita do cotovelo é ocasionalmente observada em raças de pequeno porte (Terrier, Lhasa Apso, Pug, Pinscher, etc.), manifestando-se ao nascimento ou até os 3 a 4 meses de idade, com a porção proximal da ulna tipicamente rotacionada lateralmente de 45 a 90 graus. Os sintomas incluem variados graus de claudicação e deformidade óssea. Associado com a rotaçào lateral da ulna, existe um deslocamento em relaçào ao sulco troclear, processo ancôneo e úmero. Este processo acarreta desvio lateral do antebraço, rotaçào lateral dos dígitos e redução no movimento de extensão do cotovelo. A patogênese desta condição é desconhecida, uma das teorias relatam a fracasso do desenvolvimento (aplasia) dos ligamentos colateral medial e anular e a hipertrofia do ligamento colateral lateral o qual permite a rotação lateral da ulna. Em geral, o tratamento deve ser instituido o quanto antes para se evitar os problemas com as anormalidades do crescimento. Se ele for retardado até a maturidade do animal, a severa incongruência articular levará às alterações degenerativas secundárias com pobre retorno da função. Os métodos de redução cirúrgica incluem o uso de fios temporários de Kirschner dirigidos do olécrano para o úmero, osteotomia ulnar corretiva com posterior estabilização da articulação úmero-rádio-ulnar e uso de pino transarticular de Kirschner. Este trabalho tem o objetivo de relatar o tratamento da luxaçào congênita do cotovelo ( 4 casos bilaterais) em 6 càes da raça Pinscher, com idade variando entre 30 e 40 dias. O exame físico revelou encurtamento tendíneo, rotaçào lateral dos membros torácicos e discreta atrofia muscular. $\mathrm{O}$ exame radiográfico confirmou a suspeita clínica de luxaçào congênita do cotovelo. $\mathrm{O}$ tratamento cirúrgico foi recomendado para todos os animais. Realizou-se acesso caudo-lateral e o procedimento cirúrgico consistiu na artrotomia úmero-rádio-ulnar com desmotomia lateral e capsulorrafia medial. Após redução da luxação as articulaçōes foram estabilizadas por meio da inserçào de agulhas hipodérmicas (25x7) transarticulares com posterior remoção dos canhōes e discreta dobra na ponta. Foram aplicadas bandagens rígidas durante 14 dias e as agulhas foram retiradas após 21 dias. Os pacientes demonstraram apoio no pós cirúrgico imediato sugerindo a eficiência da estabilizaçào articular com agulhas sem a necessidade do emprego de outros materias ou técnicas cirúrgicas como a osteotomia ulnar. 